\title{
DOES MONETARY POLICY AFFECT COMPETITIVENESS OF THE SLOVAK REPUBLIC?
}

\author{
Viera Pavličková ${ }^{1}$, Michaela Urbanovičová ${ }^{2}$ \\ ${ }^{1}$ Technical University of Košice, Faculty of Economics, Boženy Němcovej 32, 08001 Košice, SR \\ Email:viera.pavlickova@tuke.sk \\ ${ }^{2}$ Technical University of Košice, Faculty of Economics, Boženy Němcovej 32, 08001 Košice, SR \\ Email:michaela.urbanovicova@tuke.sk
}

\begin{abstract}
The aim of the article is to analyse the influence of monetary policy on the competitiveness of a country understood as the ability of a country to sell its goods and services on the international markets. The monetary policy is represented by the key interest rate, the monetary aggregate M3 and until December 2008 also the exchange rate SKK/EUR. The Trade Covering Ratio stands for the indicator of national competitiveness (import covered by export). We have focused on the situation in the Slovak Republic. The analysis has been split into two periods. The period of January 2004 December 2008 is connected with the preparation of the country for the entrance into the eurozone. The second examined period of January 2009 - December 2012 is the period after the euro adoption. Applied econometric analysis using the linear regression of time series has confirmed the statistical significance of the monetary policy effect on the competitiveness. The monetary aggregate and the exchange rate were significant factors before Slovakia joined the eurozone. Considerable difference between the floating exchange rates period and the period of the Slovak membership in the ERM II was not detected by the analysis. The interest rate has become the significant monetary instrument influencing the competitiveness in the period after the euro adoption.
\end{abstract}

Keywords: exchange rate, key interest rate, monetary aggregate, monetary policy, national competitiveness.

JEL classification: E52, F40

Doručeno redakci: 27.3.2012; Recenzováno: 17.12.2012; 18.2.2013; Schváleno k publikování: 19.6.2013

\section{Introduction}

Competitiveness of an economy is a broad concept without a clear definition. International institutions and economists have presented many various approaches to the national competitiveness. Some of them focus on the productivity as the only meaningful concept of competitiveness (Porter, 1990, WEF), others understand this economic category as a capacity for the welfare creation (MDI, EC). For the purposes of this paper we take over the definition considering the national competitiveness to be the ability of the companies of an economy to sell on international markets (OECD, Rose, 1997, Ganesh-Kumar, Sen and Vaidya, 2003). Hence, the focus is on the international trade (export and import data) of a country.

Various literature and studies have analyzed potential factors which can influence the level of export and import of an economy. Depending on the point of view which the authors have applied, several determinants have come up. These are the level of domestic and foreign income (Alawattage, 2009, Bahmani-Oskooee and Kutan, 2009), the real effective exchange rate (Alawattage, 2009), the volume of foreign direct investments (Aysan and Hacihasanoglu, 2007, Fontagné and Pajot, 1997, Hoekman and Djankov, 1997, Borbély, 2006), the labor costs of an employee (Aysan and Hacihasanoglu, 2007, Fagerberg, 1996, Borbély, 2006), the labor productivity (Borbély, 2006), the volume of credits to the private sector (Deutsche Bundesbank, 2007), research and development expenditures (Fagerberg, 1996, Borbély, 2006) or the monetary policy (Bergo, 2002,Ottaviano, Taglioni and di Mauro, 2007,Kowalski, Tadeusz and Pietrzykowski, 2010). 
The presented paper deals predominantly with the monetary policy as a determinant. Therefore, we firstly explain how the monetary policy decisions influence the competitiveness of an economy by introducing the exchange rate channel of the monetary transmission mechanism.

\section{Exchange rate channel}

The transmission mechanism of monetary policy can be generally defined as a process through which a central bank, using its monetary instruments, is able to affect a price level and a development of an economy. This process tends to change in the course of time and can work differently in every single country.

The transmission of monetary policy decisions is possible to describe as developing in three phases. At first, changes in the official interest rates of central bank are transmitted to the short-term market interest rates and exchange rates. Then the movements in financial prices and exchange rates interact with the spending, saving and investment behaviour of households and firms in the economy. At the end, the following change in the aggregate output indicates prices to adapt in order to restore a new balance. (Angeloni, Kashyap, Mojon, 2003)

There are several channels in the transmission mechanism of monetary policy which work parallelly. A central bank is able to impact the competitiveness of an economy through the exchange rate channel. This channel assumes a relationship between interest rates and exchange rates, floating exchange rates regime and also presupposes that financial capital is mobile internationally. In case of monetary policy tightening (interest rate raising and money supply decreasing) the currency appreciates. It causes a fall in export, a decrease of the demand for domestic goods and services, which became relatively more expensive compared with imported goods and services, and a decrease of the aggregate demand. Finally it has also effect on the price level, directly because it reduces the costs of imported goods and services and indirectly because it worsens the competitive position of domestic producers. Thus, the currency appreciation worsens the competitiveness of the economy. On the other side, monetary policy easing (interest rate decreasing and money supply increasing) depreciates the currency. Exchange rate depreciation has a positive impact on the net export and on the competitiveness of the economy. (The monetary policy committee, 2011, Č́ížek, 2012)

\section{Review of the literature}

The relationship between the monetary policy and the competitiveness of an economy has been analyzed from different perspectives. The authors have tried to find out which tools of monetary policy, in accordance with its targets, can be used to affect the development of an economy including its competitiveness.

Buiter and Miller (1981) have analysed "the consequences of stickiness in domestic costs and prices for the behaviour of international competitiveness and real output when the government announces of programme of the reduction in the rate of growth of nominal money supply." They have assumed that the money supply can be controlled precisely by the authorities.

Minford (1981) has focused "on the possible clash between monetary policy and the objective of maintaining of competitiveness." He has presupposed that independent monetary policy is possible under floating exchange rates.

Bergo (2002) claims that the competitiveness of an economy can be influenced by the exchange rate channel of the monetary policy. In case of the exchange rate straightening, 
"domestically produced goods and services become relatively more expansive than competing foreign products. Demand for domestically produced goods is thus reduced."

Lane (2006) has investigated the real effects of the European Monetary Union on all member counties. He claims that "it is so far too early to make any conclusive judgments about EMU long-term effects on their economies." There is evidence that in a monetary union, "changes in bilateral real exchange rates can now take place only through inflation differentials, since nominal exchange rates are fixed by definition."

According to Ottaviano, Taglioni and di Mauro (2007), there is a significant impact of a monetary integration on the national competitiveness within the European Monetary Union and its enlargement has helped the efforts of Europe to adjust to challenges of more competitive global environment.

Another group of analysts consider ten years of the EMU existence to be a too short period to assess the effect of the single area and the uniform monetary policy on the competitiveness of domestic companies in local and global markets (Kowalski, Tadeusz and Pietrzykowski, 2010).

This paper is devoted to extending existing studies focused on the above mentioned topic. Our aim is to analyse the influence of monetary policy on the national competitiveness. We focus on the situation in the Slovak Republic, although it has not longer been exclusively responsible for its monetary policy since 2009. However, the National Bank of Slovakia still participates in monetary policy decision-making of the eurozone.

\section{Data and Descriptive Statistics}

First of all, it is necessary to mention we have split the analysis into two periods. Because of entrance of Slovakia into the euro area in January 2009, main monetary authority has changed. Therefore, we have decided to investigate the relationship between monetary policy and competitiveness separately before and after the euro adoption. The first period lasts from M1/2004 to M12/2008 (model 1) and the second one from M1/2009 to M12/2012 (model 2). Bearing this in mind, we present data involved in models. We use monthly data.

For the variable representing national competitiveness in both analysed periods as the ability of a country to sell on the international markets the Trade Covering Ratio has been chosen. It has the following form (Borbély, 2006):

$$
T C R=\frac{X_{t}}{M_{t}}
$$

where:

$X_{t}$ represents the volume of export of a country in the period $t$,

$M_{t}$ stands for the volume of import of a country in the period $t$.

The indicator has been chosen because of its simplicity and complexity as it provides useful information on the international trade and the competitiveness of a country. The value of TCI higher than 1 indicates the competitiveness of a country as its export volume exceeds its import volume. Goods and services of the country are required in foreign countries to a larger extent than foreign goods in the domestic country. Data of the export and import of goods and services were gained from the balance of payments of Slovakia compiled by the National Bank of Slovakia. 
Monetary policy is represented by several variables which may be influenced by the monetary authority. The first selected factor influencing the national competitiveness is the monetary aggregate M3, also called "broad money". According to the Guideline of the European Central Bank for money and banking statistics (2000), the monetary aggregate M3 comprises the sum of the currency in circulation and overnight deposits, deposits with an agreed maturity of up to two years, deposits redeemable at notice of up to three months, repurchase agreements, money market fund shares as well as units and debt securities up to two years. Data are compiled by the National Bank of Slovakia and are available in its database.

Moreover, the second indicator of the monetary policy is one of the key interest rates. Precisely, the rate of the marginal lending facilities has been selected because it is the rate offered to credit institutions in order to obtain overnight liquidity from the central bank and normally provides the ceiling for the overnight market interest rate. The value of this rate affects the overnight liquidity demand of financial institutions and subsequently their fast reactions to an increased demand on the credit market and a higher supply of the capital in a short run. Until the entrance of the country into the eurozone, the National Bank of Slovakia decided on its value. After the euro adoption, the valid rate of the MLF is decided by the ECB. Data are available in the database of the NBS.

Furthermore, taking the exchange rate channel of the monetary transmission mechanism into account we have added the exchange rate SKK/EUR as a possible monetary determinant of the Slovak competitiveness before the euro adoption. We have also included the dummy parameter capturing the fact the Slovak Republic entered the ERM II on $28^{\text {th }}$ November 2006 as an obligatory condition before the euro adoption. The floating exchange rate system changed into the fixing with an oscillation interval of $\pm 15 \%$ around the parity. The NBS realised the exchange rate interventions in order to affect the SKK/EUR exchange rate. Data of the mentioned indicators were gained from the official statistics of the NBS.

Basic descriptive statistics and graphical analysis of the above mentioned variables are depicted in the Table 1 and the Figure 1. The vertical line indicates the entrance of the Slovak Republic into the eurozone.

Figure 1: Graphical analysis of model variables

Export / Import

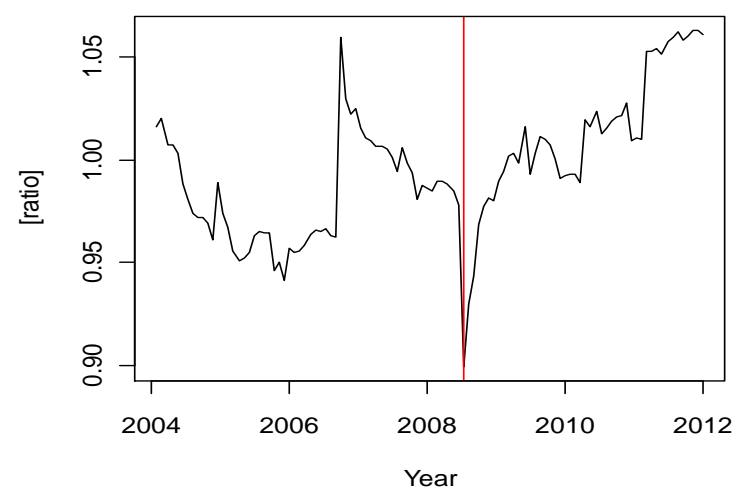

Monetary aggregate M3

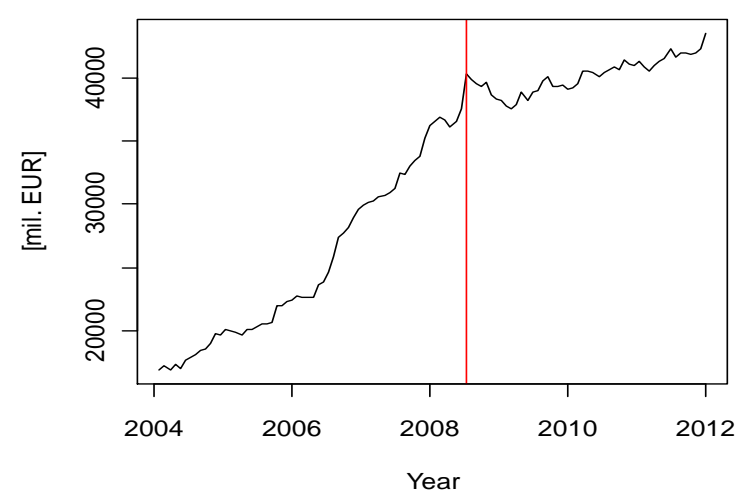




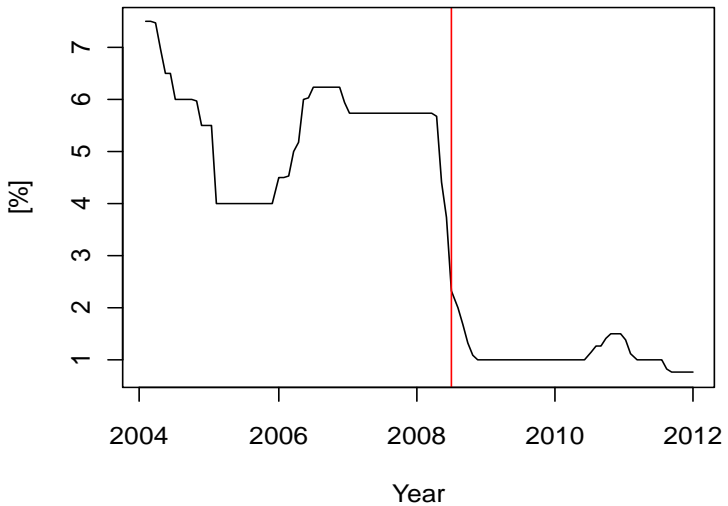

Exchange rate SKK/EUR

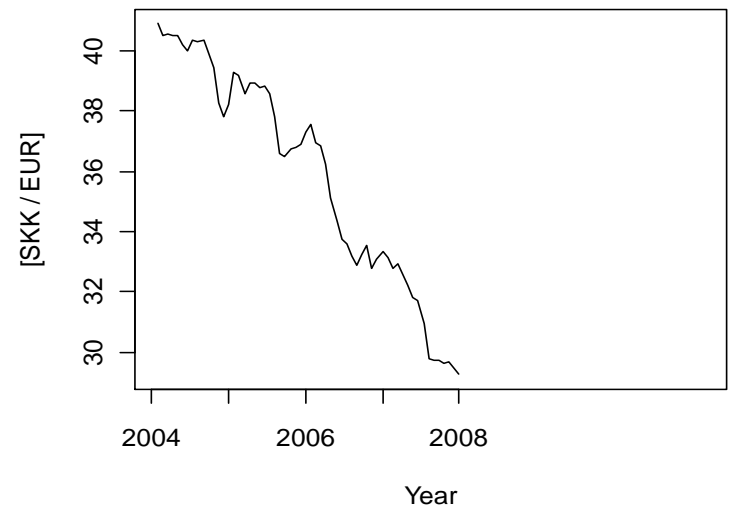

Source:

National bank of Slovakia: Data on key interest rates, monetary aggregate M3 of Slovakia. [online] [12/01/2013]. On the Internet <http://www.nbs.sk/en/home>

Eurostat: Data on Slovak export and import and the exchange rate SKK/EUR. [online]. [12/01/2013]. On the Internet <http://epp.eurostat.ec.europa.eu/portal/page/portal/eurostat/home/>

Table 1: Descriptive statistics of model variables

\begin{tabular}{|l|c|c|c|c|c|c|c|}
\hline & \multicolumn{2}{|l|}{} & \multicolumn{2}{l}{ Aggregate M3 (MA) } & \multicolumn{2}{c|}{$\begin{array}{l}\text { Interest Rate for } \\
\text { marginal lending } \\
\text { facilities (IR) }\end{array}$} & $\begin{array}{c}\text { Exchange } \\
\text { Rate } \\
\text { SKK/EUR } \\
\text { (ER) }\end{array}$ \\
\hline Period & $\mathbf{1}$ & $\mathbf{2}$ & $\mathbf{1}$ & $\mathbf{2}$ & $\mathbf{1}$ & $\mathbf{2}$ & $\mathbf{1}$ \\
\hline $\begin{array}{l}\text { Number of } \\
\text { observations }\end{array}$ & 60 & 48 & 60 & 48 & 60 & 48 & 60 \\
\hline Mean & 0.98 & 1.01 & 25444.43 & 40207.85 & 5.46 & 1.87 & 35.82 \\
\hline Standard Deviation & 0.02 & 0.04 & 6607.26 & 1363.05 & 0.98 & 0.33 & 3.65 \\
\hline Variance & 0.00 & 0.00 & 43655933.36 & 1857913.32 & 0.97 & 0.11 & 13.30 \\
\hline Median & 0.98 & 1.01 & 22721.35 & 40370 & 5.75 & 1.75 & 36.76 \\
\hline Minimum & 0.94 & 0.90 & 16918.46 & 37558 & 3.73 & 1.5 & 29.26 \\
\hline Maximum & 1.06 & 1.06 & 37576.51 & 43536 & 7.5 & 3 & 40.89 \\
\hline
\end{tabular}

Source: Authors

\section{Methodology}

In order to find out the effects of monetary policy on the competitiveness of the Slovak Republic, we have applied the linear regression. It is a statistical method for modelling the linear relationship between the response (dependent) variable $y$ and one or more explanatory (independent) variables $x_{1}, x_{2} \ldots \ldots x_{k}$.

Let $n$ be the number of observations, then the linear regression has the following form:

$$
Y_{i}=\beta_{0}+\beta_{1} x_{i 1}+\beta_{2} x_{i 2}+\cdots+\beta_{k} x_{i k}+\varepsilon_{i},
$$

where $\beta_{j}, j=0, \ldots, k$ are unknown parameters, so called regression coefficients. They can be interpreted as the expected change in y caused by the increase of $\mathrm{x}$ by 1 unit assuming no changes in other regressors $x_{i}, i=1, \ldots, k i \neq j . \varepsilon_{i}$ is random variable, so called error term, and captures all variables effecting $y$ besides $x_{i}$.

Matrix form of the equation is:

where:

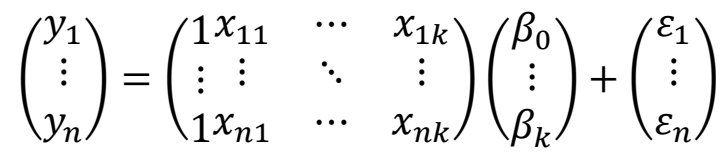




$\begin{array}{ll}y_{n \times 1} & \text { is a column vector of the dependent variable, } \\ X_{n \times(k+1)} & \text { is a matrix of the } k \text { independent variables, } \\ \beta_{(k+1) \times 1} & \text { is a column vector of the regression coefficients, } \\ \varepsilon_{n \times 1} & \text { is a column vector of the error term. }\end{array}$

The regression coefficients are unbiased if the linear model conditions are fulfilled. Hence, the model has to be submitted to tests of stationarity of variables, test of heteroscedasticity and autocorrelation of residuals and test of multicollinearity of independent variables. Finally, we do apply the test of good specification of the model.

\section{Results}

In order to test stationarity of the data, we have realized the Augmented Dickey-Fuller test. Table 2 presents the results.

Table 2: Augmented Dickey-Fuller test of stationarity

\begin{tabular}{|c|c|c|c|c|c|c|c|}
\hline & \multicolumn{4}{|c|}{ Export/Import (TCR) } & \multicolumn{2}{|c|}{ Aggregate M3 (MA) } & \multicolumn{2}{c|}{$\begin{array}{c}\text { Interest rate for } \\
\text { marginal lending } \\
\text { facilities (IR) }\end{array}$} & $\begin{array}{c}\text { Exchange rate } \\
\text { SKK/EUR (ER) }\end{array}$ \\
\hline Period & $\mathbf{1}$ & $\mathbf{2}$ & $\mathbf{1}$ & $\mathbf{2}$ & $\mathbf{1}$ & $\mathbf{2}$ & $\mathbf{1}$ \\
\hline Levels & $\mathrm{N}$ & $\mathrm{T}$ & $\mathrm{C}$ & $\mathrm{N}$ & $\mathrm{N}$ & $\mathrm{T}$ & $\mathrm{C}, \mathrm{T}$ \\
& -0.4818 & $-3.5824 *$ & 1.2317 & 1.1291 & -1.5132 & $\begin{array}{c}-5.9255 \\
* * *\end{array}$ & -3.4118 \\
\hline Differences & $\begin{array}{c}\mathrm{C} \\
-6.4079 \\
* * *\end{array}$ & $\begin{array}{c}-4.4802 \\
* * *\end{array}$ & $\begin{array}{c}-4.3454 \\
* * *\end{array}$ & $\begin{array}{c}-4.5742 \\
* * *\end{array}$ & $\begin{array}{c}-3.2566 \\
*\end{array}$ & $\begin{array}{c}-4.1113 \\
* * *\end{array}$ & $\begin{array}{c}\mathrm{C} \\
* * *\end{array}$ \\
\hline
\end{tabular}

$\mathrm{T}$ - trend + constant, $\mathrm{C}$ - constant, $\mathrm{N}$ - none

Signif. codes: 0 '***' 0.001 '**' 0.01 '*' 0.05 '? 0.1 ' ' 1

Source: Authors

Based on the results of the ADF test the hypothesis of stationarity cannot be rejected at the $5 \%$ level of significance in case of differences. Hence, we can assume the stationarity of all the analyzed time series expressed through the differences of the variables and move on to test the assumptions of the linear models. As mentioned earlier, the model for the period of 20042008 also involves exchange rate as an independent variable. Thus, the model has the following form:

$$
\left(T C R_{t}-T C R_{t-1}\right)=\beta_{0}+\beta_{1}\left(M A_{t}-M A_{t-1}\right)+\beta_{2}\left(I R_{t}-I R_{t-1}\right)+\beta_{2}\left(E R_{t}-E R_{t-1}\right)+\text { Dummy }_{t}+u_{t},
$$

where $T C R_{t}-T C R_{t-1}, M A_{t}-M A_{t-1}, I R_{t}-I R_{t-1}$ and $E R_{t}-E R_{t-1}$ represent the intermonth changes of the variables Trade Covering Ratio, Aggregate M3, the interest rate for MLF and exchange rate SKK/EUR respectively.

The model for the second period of 2009-2012 excludes exchange rate as the Slovak Republic has already adopted euro. It can be written as follows:

$$
\left(T C R_{t}-T C R_{t-1}\right)=\beta_{0}+\beta_{1}\left(M A_{t}-M A_{t-1}\right)+\beta_{2}\left(I R_{t}-I R_{t-1}\right)+u_{t} .
$$

The models were submitted to the Durbin-Watson and the Breusch-Godfrey tests of autocorrelation of residuals, the Breusch-Pagan test of heteroscedasticity of residuals, test of multicollinearity realised using the Variance Inflation Factor and the reset test of good model specialisation. The resulted models fulfil all the requirements of a linear model based on the 
mentioned tests on the level of significance of $5 \%$; hence, the regression coefficients may be considered unbiased (Table 3, Table 4).

Table 3: Testing assumptions of the linear regression

\begin{tabular}{|l|l|c|c|}
\hline \multicolumn{2}{|c|}{ Model } & $\mathbf{1}$ & $\mathbf{2}$ \\
\hline Heteroscedasticity of residuals & Breusch-Pagan test - p value & 0.6441 & 0.4776 \\
\hline Autocorrelation of residuals & Durbin-Watson test - DW statistics & 0.9024 & 0.6698 \\
\hline Model specification & Reset test - p value & 0.6532 & 0.7659 \\
\hline
\end{tabular}

Source: Authors

Table 4: VIF value

\begin{tabular}{|l|c|c|}
\hline Model & $\mathbf{1}$ & $\mathbf{2}$ \\
\hline diffMA & 1.291638 & 1.045239 \\
\hline diffIR & 1.010284 & 1.045239 \\
\hline diffER & 1.300699 & - \\
\hline
\end{tabular}

Source: Authors

Considering the regression results, we look at the two analysed models separately. Table 5 presents the results of the model for the first period before the euro adoption.

Table 5: Model 1: Test of significance of independent variables

\begin{tabular}{|l|c|c|c|c|}
\hline & Estimate & Std. Error & t value & p value \\
\hline Intercept & 0.0008918 & 0.002506 & 0.356 & 0.7232 \\
\hline$M A_{t}-M A_{t-1}$ & -0.000009963 & 0.000004949 & -2.013 & $0.0490 *$ \\
\hline$I R_{t}-I R_{t-1}$ & 0.005494 & 0.005886 & 0.933 & 0.3547 \\
\hline$E R_{t}-E R_{t-1}$ & -0.01163 & 0.005016 & -2.320 & $0.0241 *$ \\
\hline Dummy $_{t}$ & 0.003642 & 0.004315 & 0.844 & 0.4024 \\
\hline
\end{tabular}

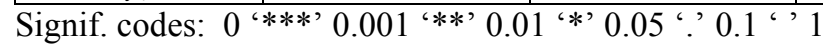

Source: Authors

In general, the period before the euro adoption was characterized by the sharp real economic growth, appreciation of the domestic currency, several reforms, the entry of investments and the rise of export. With respect to the results of the model, the monetary aggregate M3 and the exchange rate SKK/EUR disposed of statistically significant impact on the trade covering ratio as a measure of the competitiveness of Slovakia on the 5\% significance level. The effect of the interest rate of the MLF appeared to be insignificant.

Negative influence of the development of the monetary aggregate was contrary to the theory of the transmission mechanism. However, it was likely caused by changes in the factors which influence the efficiency of the transmission mechanism and disruption of the relations between the particular criterions and the main target of the NBS. The combination of the monetary easing and the strong economic growth did not led to the domestic currency depreciation but to its appreciation. Therefore, the rise of the monetary supply caused the decreasing of the competitiveness.

Considering the exchange rate, generally, the appreciation causes the decrease of the competitiveness. However, the currency appreciation in Slovakia in analysed period led to the better position on the international market. In this case the rise in the net export was influenced by expectations of higher inflation after the adoption of the new currency. Moreover, no statistically significant difference was observable after the entrance of the country into the ERM II. This might be explained by the wide oscillation bands and twofold change of the parity with respect to the economic situation. Hence, the development of the exchange rate was not limited by the exchange rate system. 
As far as the second period of 2009-2012 is concerned, the results are slightly different. (see table 6)

Table 6: Model 2: Test of significance of independent variables

\begin{tabular}{|l|c|c|c|c|}
\hline & Estimate & Std. Error & t value & $\mathrm{p}$ value \\
\hline Intercept & $2.967 \mathrm{e}-03$ & $1.675 \mathrm{e}-03$ & 1.771 & 0.0834. \\
\hline$M A_{t}-M A_{t-1}$ & $-6.110 \mathrm{e}-06$ & $3.394 \mathrm{e}-06$ & -1.800 & 0.0787. \\
\hline$I R_{t}-I R_{t-1}$ & $-2.758 \mathrm{e}-02$ & $1.490 \mathrm{e}-02$ & -1.851 & 0.0708. \\
\hline
\end{tabular}

Signif. codes: 0 ‘***’ $0.001^{\text {‘**’ }} 0.01$ '*’ $0.05^{\prime}$.' $0.1^{\text {‘ ’ } 1}$

Source: Authors

The period after Slovakia joined the eurozone could be described by the slower real economic growth, the high unemployment and the worsened situation on the international market.

Considering the results, except for the monetary aggregate M3, the interest rate of the MLF was also significant on the significance level of $10 \%$. The monetary aggregate influenced the TCR negatively what corresponds to the results from the first period. However, the impact was slightly smaller which might be connected to the shift of main monetary duties from the NBS to the ECB which do not respect particular needs of each involved country.

The influence of the interest rate changes is also negative what is in line with the exchange rate transmission mechanism. Hence, the monetary easing realised by the ECB through the interest rate of the MLF caused the exchange rate depreciation. Consequently the net export raised and the competitiveness of the economy got better. However, in this period the model has indicated smaller absolute influence of changes in monetary aggregate to the development of the Trade Covering Ratio compared with the first examined period. Hence, the overall competitiveness of Slovakia worsened.

\section{Conclusion}

The competitiveness of an economy as the ability to succeed with its products in the international competition is an economic category strongly influenced by several factors. Many authors pay attention to the national competitiveness changes caused by an integration process and monetary policy decision-making.

In this study the impact of monetary policy on the competitiveness of the Slovak Republic in the two separate periods (from M1/2004 to M12/2008 and from M1/2009 to M12/2012) has been quantified using the multiple linear regression. The analysis of this paper has proved the role of the monetary policy in affecting the competitiveness.

Within the first analysed period, the impact of the monetary aggregate and the exchange rate was significant. However, no change after the entrance of the country in the ERM II was proved. The second period showed weaker influence of the monetary aggregate. On the other hand, interest rate was a significant factor. However, the Slovak Republic is the member of the EMU only from 2009 and it is too early to make any conclusive judgments about how efficiently the monetary mechanism of the EBC is.

We realise the outcome of the analysis is influenced by the measure of competitiveness we have chosen. Therefore, there is still scope to examine the impact of the monetary policy on the competitiveness of the economy from other perspectives using different approaches. 


\section{Acknowledgement}

The paper is supported by the grant VEGA 1/0973/11 „Monetary Rules and Their Significance in the context of a Monetary Union and the Economic Crisis“.

\section{References}

[1] AlaWATtAGE, U. P., 2009. Exchange Rate, Competitiveness and Balance of Payments Performance. Central Bank of Sri Lanka: Staff Studies, 34(1).

[2] ANGELONI, I., A. K. KASHYAP and B. MOJON, 2003. Monetary Policy Transmission in the Euro Area: A Study by the Eurosystem Monetary Transmission Network. Cambridge: Cambridge University Press. ISBN 9780521828642.

[3] AYSAN, A. F. and Y. S. HACIHASANOGLU, 2007. The Competitiveness of Turkey with Respect to the Slovak Republic for the 1995-1999 Period. Munich Personal RePEc Archive, [online]. Paper No. 5496 [19/06/2011]. On the Internet: http://mpra.ub.unimuenchen.de/5496/1/MPRA_paper_5496.pdf

[4] BAHMANI-OSKOOEE, M. and A. KUTAN, 2009. The J-curve in the emerging economies of Eastern Europe. Taylor and Francis Journals, 41(20), p. 2523-2532. ISSN 0740-770X.

[5] BALTAGI, B. H., 2008. Econometrics. Berlin: Springer-Verlag. ISBN 978-3-540 76515-8.

[6] BERGO, J., 2002. Monetary Policy, Cyclical Fluctuations and Competitiveness. BIS Review [online]. $49 \quad[12 / 01 / 2012] . \quad$ On the Internet: http://www.bis.org/review/r020910c.pdf?frames=0

[7] BORBÉLY, D., 2006. Trade Specialization in the Enlarged European Union. Heidelberg: Physica-Verlag. ISBN 978-3-7908-1704-1.

[8] BUITER, W. H. and M. MILLER, 1987. Monetary policy and international competitiveness: The problems of adjustment. Oxford economic paper, 33, p. 143 175. ISSN $1464-3812$.

[9] Current Account Balances and Price Competitiveness in the Euro Area. Deutsche Bundesbank. Monthly Report. June 2007

[10] ČÍŽEK, B., 2012. Nastavení měnově-politických vazeb ve vztahu k úvěrové a ekonomické aktivitě. Acta academica karviniensia, 4, p. 5 - 14. ISSN 1212-415X.

[11] Data on key interest rates, monetary aggregate M3 of Slovakia. [online]. National Bank of Slovakia. [12/01/2013]. On the Internet: http://www.nbs.sk/en/home

[12] Data on Slovak export and import and the exchange rate SKK/EUR. [online]. Eurostat. [12/01/2013]. On the Internet:

http://epp.eurostat.ec.europa.eu/portal/page/portal/eurostat/home/

[13] FAGERBERG, J., 1996. Competitiveness, Scale and R\&D. Technology and International Trade, UK: Edward Elgar Publ. Ltd., p. 38-54. ISBN 1-85898- 528-5

[14] FONTAGNÉ, L. and M. PAJOT, 1997. How Foreign Direct Investment Affect International Trade and Competitiveness: an Empirical Assessment. CEPII, document de travail no 97-17. 45 p.

[15] GANESH-KUMAR, A., K. SEN and R. R. VAIDYA, 2003. International Competitiveness, Investment and Finance: A Case Study of India. New York: Routledge. ISBN 0415312329 
[16] HOEKMAN, B. and S. DJANKOV, 1997. Determinants of the Export Structure of Countries in Central and Eastern Europe. The World Bank Economic Review, 11(3), p. 471 - 487. ISSN 0258-6770.

[17] KOWALSKI, T. and M. PIETRZYKOWSKI, 2010. The economic and monetary union vs. shifts in competitiveness of member states. MPRA Paper No. 33995. Working papers, Faculty of International Business and Economics WP/2010/05, p. 130.

[18] KWIATKOWSKI, D., P. C. B. PHILLIPS, P. SCHMIDT and Y. SHIN, 1992. Testing the null of stationarity against the alternative of a unit root: How sure are we that economic time series have a unit root? Econometrics, 54, p. 159-178.

[19] LANE, P. R., 2006. The real effects of European monetary union. The Journal of Economic Perspective, 20(4), p. 47 - 66. ISSN 0895 - 3309.

[20] MINFORD, P., 1981. The exchange rate and monetary policy. Oxford economic paper, 33, p. 120 - 142. ISSN 1464 - 3812.

[21] OECD, 1992. Technology and the Economy: the Key Relationships. Paris: OECD. ISBN 92-641-3622-3.

[22] OTTAViano, G., D. TAGLIONI and F. di MAURO, 2007. Deeper, Wider and More Competitive? Monetary Integration, Eastern Enlargement and Competitiveness in the European Union. ECB Working Paper Series, No 847. ISSN 1725-2806

[23] PORTER, M. E., 1990. The Competitive Advantage Of Nations. Harvard Business Review [online] p. 73-91 [01/02/2011]. ISSN 0017-8012 On the Internet: http://asesoriainternacional.com/Clases\%20URN/The_Competitive_Advantage_of_Na tions.pdf

[24] ROSE, A. K., 1997. Dynamic Measures of Competitiveness: Are the Geese Still Flying in Formation? [online] [23/06/2011]. On the Internet: http://faculty.haas.berkeley.edu/arose/frbsflet.ps.pdf

[25] The European Central Bank, 2012. Guideline of the European Central Bank for money and banking statistics 2000. Frankfurt on the Main: Eurostat. ISBN 92-9181-145-9

[26] The Gobal Competitiveness Report 2010-2011 [online]. Geneva: World Economic Forum, $2010 \quad$ [01/02/2011]. On the Internet: http://www3.weforum.org/docs/WEF_GlobalCompetitivenessReport_2010-11.pdf

[27] The monetary policy committee, Bank of England. The transmission mechanism of monetary policy London, 2011 [online]. [14/03/2013]. On the Internet: http://www.bankofengland.co.uk/publications/Documents/quarterlybulletin/Montrans. pdf

[28] World Competitiveness Yearbook 2011, 2011. Geneva: Institute for the Management Development [online]. [24/06/2012]. On the Internet: http://www.imd.org/research/publications/wcy/wcy_online.cfm 